\title{
ReSEARChArticle \\ Comparative nutritional evaluation of pods of Leptadenia pyrotechnica from three different regions of Rajasthan
}

\author{
Mala Rathore
}

\section{SUMMARY}

Leptadenia pyrotechnica (Khimp) is a small shrub belonging to family Asclepiadaceae found growing in the arid zone of Rajasthan. It has ethnopharmacological importance and known for its stem fibre. Its edible unripe fruits contribute significantly to the food and energy needs of rural populations. These are known as khimpoli and cooked as vegetable. Comparative evaluation of nutritional composition of the pods from different regions of Rajasthan was carried out so as to promote these underutilised fruits. Analysis was carried out using standard AOAC methods. Fruits were found to be rich in ash (5.03\% to $5.57 \%$ ), fat (5.35\% to $6.82 \%$ ), protein (13.28\% to $18.56 \%)$, sugar (5.61 \% to $6.54 \%$ ), vitamin C (66.62 to $90.1 \%$ ) and minerals viz., $\mathrm{Cu}, \mathrm{Zn}, \mathrm{Fe}, \mathrm{Mn}, \mathrm{Mg}, \mathrm{P}, \mathrm{K}, \mathrm{Ca}$ and $\mathrm{Na}$. Results indicated that khimp pods can be promoted as supplementary food in arid region.

Key Words : Khimp, Pods, Minerals, Underutilized, Supplement, Sugar, Protein

How to cite this article : Rathore, Mala (2021). Comparative nutritional evaluation of pods of Leptadenia pyrotechnica from three different regions of Rajasthan. Internat. J. Plant Sci., 16 (2): 155-159, DOI: 10.15740/HAS/IJPS/16.2/155-159, Copyright@ 2021: Hind Agri-Horticultural Society.

Article chronicle : Received : 19.04.2021; Revised : 03.05.2021; Accepted : 05.06.2021 